\title{
Challenges in Ethiopia's Post-1991 Ethnic Federalism Entwined with Ethnic-based Political Parties
}

\begin{abstract}
For about two and a half decades (1991-2018) it was propagated that Ethiopia's ethno-linguistic federalism was primarily meant to unify the state and build the nation. However, competing perspectives on whether ethnic-based federalism would preserve unity in diversity in the country as a whole and in regional states in particular have proliferated. This article examines the outcome of post-1995 Ethiopian federalism in ethnic conflict management. It focuses on why Ethiopia has remained deeply divided and prone to ethno-cultural conflicts despite the ethno-linguistic federal political system, which was adopted as a mechanism for building unity in diversity in the context of peaceful coexistence among various ethno-linguistic groups. Although ethnic-federalism alone may not exacerbate ethnic conflicts, ethnic-federalism entwined with the existence of ethnic-based political parties and the rapid proliferation of narrow ethno-nationalist politics constitute major impediments to peaceful co-existence among the country's ethnic groups. Furthermore, the land ownership questions raised by various ethno-linguistic political elites are among the causes of violent ethnic conflicts in contemporary Ethiopia. Mistreatment of ethnic minorities in all regional states is also a source of ethnic conflict. I argue that the current government at the federal and regional levels should work hard to ensure that identity-based politics will incrementally dissolve like salt in water.
\end{abstract}

\section{Key terms:}

Ethnic Federalism · Political Parties · Ethnic Conflict · Ethiopia

DOI http://dx.doi.org/10.4314/mlr.v15i2.1

This article is licensed under a Creative Commons Attribution-

NonCommercial-NoDerivs (CC BY-NC-ND)

Received: 31 July 2021

Accepted: 9 November 2021

\section{Suggested citation:}

Muluneh Kassa Eresso (2021), “Challenges in Ethiopia's Post-1991 Ethnic

Federalism Entwined with Ethnic-based Political Parties”, 15(2) Mizan Law Review:

313-350

\footnotetext{
* Muluneh Kassa Eresso (PhD), Assistant Professor in Federalism and Governance Studies at the African Leadership Excellence Academy

E-mail: mulunehkassa@yahoo.com

ORCID: https://orcid.org/0000-0001-5527-7160
} 


\section{Contents}

Abstract

1. Introduction

2. Ethnic and Territorial Federalism: Conceptual Clarifications

2.1 Salient features of ethnic federalism and the need for moral standards and reason

2.2 Geographic Federalism

3. The Evolution of Ethnic Federalism in Ethiopia

4. Competing Claims for Ethnic and Territorial Federalism in Ethiopia

4.1 The arguments against and in favour of Ethiopia's ethnic federalism

4.2 The need for synthesis in perspectives

5. Federalism and Ethnic Party Politics in Ethiopia: Some Observations

6. Inter-Regional Boundary Disputes and Contentious Land-Ownership Claims

6.1 Metekel, Raya, and Wolkait

6.2 The boundary dispute between BGRS and the Oromia regional state

7. Examining the Experience of Ethnic Minority Management at the State

Level: A Brief Overview

8. Concluding Remarks

\section{Introduction}

Ethiopia is Africa's second largest and second most populated country, located in the Horn of Africa. Ethiopia's population is estimated to be about 110 million, and comprises more than 85 ethno-linguistic groups. The post1991 period has witnessed a new political arrangement in the history of Ethiopia. The Ethiopian federal constitution, which was adopted in December 1994 and put into effect in August 1995, introduced an ethnolinguistic federal political arrangement. The current federal state structure comprises eleven regional states (Tigray, Afar, Amhara, Oromia, Somali, Benishangul Gumuz, SNNP (Southern Nations, Nationalities, and Peoples), Gambella, Sidama, South Western Ethiopia Peoples and Harari) with two city administrations such as Addis Ababa and Dire Dawa. 
It is obvious that diversity is one of the most contested issues in domestic and international politics. ${ }^{1}$ Questions concerning how diversities should be recognized and accommodated in ethno-linguistically and culturally heterogeneous states are currently among the most important political agenda for democratic and democratizing societies. ${ }^{2}$ Currently, accommodation of diversity has been a salient issue in developed and developing states. In this respect, the Tigray People's Liberation Front (TPLF)-dominated Ethiopian People Revolutionary Democratic Front (EPRDF) propagated that the overarching aim of ethno-linguistic federalism, which has been adopted in Ethiopia since 1991, was primarily to unify the state and build the nation.

Unfortunately, however, in its founding manifesto, the TPLF had expressed its objectives of independence from Ethiopia and establishing the greater republic of Tigray. This manifesto can be considered as the foundation for the recognition of the constitutional guarantee for selfadministration up to the point of secession. As John Markakis indicated, the EPRDF was established in 1989 under the dominating influence of the TPLF and its ally, the Ethiopian People's Democratic Movement (EPDM). ${ }^{3}$

Indeed, in post-1991 Ethiopia, competing views have been forwarded on whether ethnic-based federalism would maintain unity in diversity in the country as a whole, and in regional states in particular. The major objective of this article is to critically investigate the pathologies and triumphs of federalism in Ethiopia. With this in mind, the article examines the factors behind internecine ethno-cultural conflicts despite having an ethno-linguistic federal political system in place, which was adopted as a mechanism for building unity in diversity and endorsing peaceful coexistence among various ethno-linguistic groups.

This article is organized into six sections. The next section provides a conceptual clarification of ethnic and territorial federalism. Section 3 discusses the evolution of ethnic federalism in Ethiopia. The fourth section examines the competing claims for ethnic and territorial federalism in

\footnotetext{
${ }^{1}$ L. Moreno, and C. Colino in Moreno, L. and Colino, C. eds., (2010), A global dialogue on federalism, diversity and unity in federal countries. Vol. 7, McGill -Queen's University.

2 A. Gutmann (1994), Multiculturalism: Examining the Politics of Recognition. 41 William Street: Princeton University. And also see Assefa Fiseha (2007), Federalism and the Accommodation of Diversity in Ethiopia: A Comparative Study, Revised Edition, Addis Ababa: Artistic Printing Enterprise.

${ }^{3}$ M. John (2011), Ethiopia: The Last Two Frontiers, Oxford, England: James Currey.
} 
contemporary Ethiopia. Section 5 attempts to review federalism and ethnicbased party politics in fomenting ethnic conflicts in contemporary Ethiopia. The sixth section examines inter-regional boundary disputes and contentious land-ownership claims in the country. Section 7 attempts to examine the management of ethnic minorities at a regional state level. The final section provides concluding remarks.

\section{Ethnic and Territorial Federalism: Conceptual Clarifications}

\subsection{Salient features of ethnic federalism and the need for moral standards and reason}

The term ethnic federalism is a descriptively accurate term for a federation in which subunits are specifically drawn to coincide with the geographic distribution of ethnic groups. ${ }^{4}$ It refers to a federation based on geographically separated ethno-linguistic and religious groups. Ethnic federalism legitimizes the autonomous self-government of ethno-cultural communities, implying that the states are territorially organized along ethnic lines. Ethnic federalism is defined by Hale as "a federal state in which at least one constituent territorial governance unit is intentionally associated with a specific ethnic category". 5 According to Roeder, ethnic federalism is a type of federalism "in which at least some, if not all, of the constituent units of the federation are homelands controlled by their respective ethnic groups". ${ }^{6}$ This indicates that ethnicity is a major defining feature of the system. Nevertheless, the definition of ethnic federalism proposed by Roeder and Hale seems to refer to a mixed (ethnic and geographic) form of federal arrangement rather than pure ethnic federalism. They noted that some, if not all, of the federation's constituent units are ethnically controlled homelands.

Ethno-linguistic federalism is a preferred system of government in some countries. The reason for this is to accommodate the interests of various ethnic groups. It is one important tool of conflict management, typically in an ethno-linguistically divided society. However, scholars have claimed that ethnically defined federal arrangements are prone to a variety of pathologies; they harden, rather than alleviate, ethnic identities; they empower extremist

\footnotetext{
${ }^{4}$ D. Anderson (2012), Federal Solutions to Ethnic Problems: Accommodating Diversity, Routledge

5 H. Hale (2004), 'Divided We Stand: Institutional Sources of Ethno federal State Survival and Collapse', World Politics, 56, pp. 165-193.

${ }^{6}$ P. Roeder (2009), 'Ethno federalism and the Mismanagement of Conflicting Nationalisms', Regional and Federal Studies, 19(2), pp. 203-219.
} 
ethnic leaders; they foster a zero-sum political dynamic at the center; they elevate a 'primitive' form of identity over more elevated, progressive identities; they generate periodic state crises because they are unable to achieve equilibrium; and, ultimately, they equip ethnic groups with the resources needed to challenge the territorial integrity of the common-state. ${ }^{7}$

Several scholars acknowledge that a federal system based solely on ethnicity fragments a country by creating new problems rather than resolving the majority of the problems. In support of this argument, various scholars on this field have presented evidence in the cases of the defunct federations of the USSR, Yugoslavia, Czechoslovakia, Pakistan, and Malaya-Singapore. On the contrary, by resolving their differences, a few countries (that have adopted ethno-linguistic federalism) have been able to strengthen their national unity. India, Belgium, and Canada can be mentioned as examples.

In this respect, it might be noted that proper administration of the ethnicbased federal system necessitates the utmost care and wisdom of leaders. It is also essential not to overlook the importance of people's well-being. If the majority of governmental action is taken for the right reasons, it can play a significant positive role in resolving ethnic disputes rather than creating new problems. Another vital consideration while implementing an ethnic-based federal system is that leaders and people must have a strong culture of pursuit towards enhanced awareness, rational thinking and higher values of respect for the intrinsic worth of human dignity, equality, fraternity and moral standards. These virtues of reason and morality are needed to the system's proper functioning. They are manifested by informed cognition and positive volition among the people and leaders in the context of shared aspirations.

One of the major questions that arises at this juncture relates to the issue of corruption and good governance that challenged the proper functioning of federalism and national unity during the TPLF-led EPRDF's regime. The problem of ethnically orchestrated rampant governmental corruption and a lack of good governance were widespread. In reality, ethnic conflicts are bolstered primarily by self-interest under the guise of his or her own group while on the contrary leaders must uphold and properly enforce the laws.

${ }^{7}$ See for instance, Roeder (2009), Bunce (1999), Bunce and Watts (2005), Aitken (2007), Hale (2004), Snyder (2000), and Horowitz (2002) in Anderson, supra note 4. 
According to Kant, "an action can have moral worth if and only when it is done as a duty". ${ }^{8}$ His argument should be considered in at least every government action. As Grotius observed, humans are endowed with the ability to judge whether something is or will be pleasant or harmful. ${ }^{9}$ It is obvious that people in a divided society should not only respect but also value one another's cultures and languages. The idea is that respecting and valuing diversity has been identified as a component of morality. It is important to underscore at this point that strong morality and rationality are not only necessary within the framework of an ethnically structured federal system, but they also demonstrate that morality and rationality are indispensable in ethnically structured political systems. Indeed, morality and reasonableness among the leaders and the people are essential for any country that strives to build a strong democratic system.

It should be noted that strong morality and rationalism among leaders at various levels of government are important to recognize that the federal system based on ethnicity is far more complex and sensitive than other nonethno-linguistic federal systems. The multifaceted needs and questions raised by various ethno-linguistic groups are at the root of the complications. It is widely visible in contemporary Ethiopia that some groups or individuals assume that their own ethnic group members are not the source of the problems and, as a result, they perceive that the problems are not theirs.

Furthermore, the 'oppressor and oppressed' narrative that is disseminated by several political elites has disrupted the peaceful coexistence of various ethnic groups. Hence, in order to strengthen national unity and strengthen the peaceful coexistence of nations, it is argued that due recognition to past political achievements and restraint from fixations on past political injustices as a political culture among the ethno-linguistic groups is indispensable thereby enabling societies to focus on current positive pursuits and shared aspirations.

\subsection{Geographic Federalism}

Geographic federalism is a government system that poses a direct and significant challenge to the fundamental idea of defining subunits in a federation based on ethnicity. The geographic model of federalism does not embrace ethnicity as the system's defining principle; nor are boundary lines drawn with the specific intent of denying ethnically homogeneous

\footnotetext{
${ }^{8}$ S. Philip (2000), Kant, Duty and Moral Worth, London, Routledge.

${ }^{9}$ Peter Judson Richards (2008), 'Hugo Grotius, Hosti Humani Generis, and the Natural Law in Time of War,' Liberty University Law Review, Vol. 2, pp. 881-908.
} 
constituent units and sub-units. The logical implication is that ethnicity is largely ignored in the design of the federal system. According to Gordon, in the territorial model of federalism, "there is no coincidence between ethnic groups and state [or sub-state] boundaries". ${ }^{10}$ The central idea is that ethnicity has no bearing on the definition of the federation's units and subunits. Geographical locations demarcate the boundaries of constituent units and subunits. Its main goal is to keep the state neutral in terms of different ethno-linguistic groups.

Geographic federalism divides large ethnic concentrations into smaller constituent units and sub-units in an effort to realize the integration of various ethno-linguistic groups. ${ }^{11}$ Geographic federalism was primarily designed not to address ethno-linguistic challenges but rather to produce a more efficient form of government. Geographic federalism focuses of convenience and efficiency that may divide up the power of a dominant ethnic group. ${ }^{12}$ This model of federalism targets the universal protection of individual rights rather than group rights. Examples of this model include the United States, Australia, Pakistan, and post-1967 Nigeria. The Malaysian federal system is also categorized under territorial federalism.

The structure of Nigeria's federal system evokes a number of controversies. Several scholars argue that the structure of Nigerian federalism is not entirely geographical. According to this argument, Nigeria's federal state structure is geographical as per the constitution, but in practice, it is difficult to consider it as an entirely geographic federal state structure because some of the regions are subordinate to the same ethnic group as in the case of Bayelsa that is dominated by Ijaw, Borno by Kanuri, Edo by Edo, and so on. ${ }^{13}$ Furthermore, in support of this argument, Anderson ${ }^{14}$ and Ejobowah ${ }^{15}$ have indicated that, in practice, there is a high degree of interplay between ethnic groups and state boundaries in the Nigerian federation. However, the Nigerian government claims that the country's federal system is geographical.

\footnotetext{
${ }^{10}$ Brendan O'Leary (2004), 'Building Inclusive States,' Human Development Occasional Papers (1992-2007) HDOCPA-2004-09, Human Development Report Office (HDRO), United Nations Development Programme (UNDP).

${ }^{11}$ Anderson, supra note 4.

12 Ibid.

${ }^{13}$ Sklar, 2004 in Ibid

${ }^{14}$ Anderson, supra note 4.

15 J. Ejobowah (2001), Competing Claims to Recognition in the Nigerian Public Sphere: A Liberal Argument about Justice in Plural Societies, Lanham: Lexington Books.
} 
Investigation of comparative experience of federal state structures in various countries clearly shows that geographical federalism is more successful than ethno-linguistically based federalism. The hallmark of this notion is that the federal systems based on ethno-linguistic identity have disintegrated. As indicated above, the Soviet Union, Yugoslavia, and the Czech Republic are examples in this regard.

Yet, it is incorrect to consider geographical federalism as an ideal state structure for all countries. Empirical evidence reveals that various groups are challenging the structure of geographical federalism, which is being implemented in multicultural countries. Moreover, it is not possible to regard geographical federalism as a completely independent structure. As previously stated, the structure of Nigeria's federal system, for example, is not purely geographical. It is being tested by self-governance issues. Yonatan states:

The major criticism of this type of internal unit demarcation is that it denies ethnic groups territorial autonomy. By failing to provide a homeland for geographically concentrated ethnic groups, it denies them the territorial space necessary to promote their identity. In addition to this, it also makes cultural groups continuously vulnerable to the majority group's dominant position or, in some cases, to the historically dominant group. ${ }^{16}$

\section{The Evolution of Ethnic Federalism in Ethiopia}

Scholars have different justifications pertaining to why different states have adopted federalism. Riker argued that the two major reasons why states adopted federalism were expansion and military conditions. ${ }^{17}$ Riker explained that the two main issues were always present and necessary for the creation of federalism:

[First] the politicians who offer the bargain desire to expand their territorial control, usually either to meet an internal military or diplomatic threat or to prepare for military or diplomatic aggression and aggrandizement. But, though they desire to expand, they are not able to do so by conquest, because of either military incapacity or ideological distaste. Second, politicians who accept the bargain, giving up some independence for the sake of the union, are motivated by

16 Yonatan Tesfaye (2010), Ethnic Diversity and Federalism Constitution Making in South Africa and Ethiopia, England: Ashgate Publishing Company.

${ }^{17}$ W. Riker (1964), Federalism: Origin, Operation, and Significance. Boston; Toronto: Little Brown and Company. 
some external military-diplomatic threat or opportunity. Either they desire protection from an external threat or they desire to participate in the potential aggression of the federation. ${ }^{18}$

Riker's main assumption is that federalism is an outcome of institutional bargaining among politicians. ${ }^{19}$ Kenneth Wheare holds a similar view and states that an external threat and economic advantages induce the creation of any federalism. ${ }^{20}$ However, the reason why Ethiopia designed and adopted ethno-linguistic federalism was primarily to address the 'national question', a popular motto (since the 1960s) during the struggle against Ethno-linguistic domination. ${ }^{21}$

Although the majority of the political parties in power during the formative stage of the federal state structure (since 1991) advocated for the recognition and preservation of ethnic rights, some political parties were Pan-Ethiopinists during the formative stage. For example, the Ethiopian Democratic Coalition, Ethiopian Democratic Union, and Ethiopian National Democratic Organization were some of the Pan-Ethiopianist political parties during the formative stage of the federal arrangement in Ethiopia. However, their participation was extremely limited.

As Nicole Stremlau notes, there was a lack of participation by those who were not EPRDF supporters or members during the drafting of the FDRE Constitution. ${ }^{22}$ Due to the limited participation of Pan-Ethiopianist political parties at the time, the federal system merely focused on ethnic differences. It is discernible that the TPLF-dominated EPRDF opened the door for a federal arrangement with a focus on differences alone. Therefore, it can be argued that this type of administrative political approach has been a major problem in the country and is one of the main reasons for its negative impact on national unity.

18 William Riker in Craig Volden (2004), 'Origin, Operation, and Significance: The Federalism of William H. Riker', Publius: The Journal of Federalism, 34 (4), pp. 89-108.

${ }^{19}$ M. Filippov (2005), 'Riker and Federalism', Constitutional Political Economy, vol. 16, pp. 93-111. Doi: 10.1007/s10602-005-2230-x.

${ }^{20}$ K. Wheare (1963), Federal Government, $4^{\text {th }}$ edition, London: Oxford University Press.

${ }^{21}$ J. Markakis (2003), 'Conflict in pre federal Ethiopia', First national conference on federalism, conflict and peace building Addis Ababa: Ministry of Federal Affairs, pp. $11-24$.

22 Nicole Stremlau (2014), Media, Participation and Constitution-Making in Ethiopia. Journal of African Law, 58, pp. 231-249. Doi: 10.1017/S0021855314000138 
The other extreme of undermining diversity (that prevailed during most of Ethiopia's history) was problematic. Before the EPRDF came to power, ethno-linguistic diversity was not reflected in government policy. Diversity was seen as a threat or burden to political stability in Ethiopia. As a result, to minimize the threats, successive governments applied policies that aimed at transforming heterogeneous groups into a homogeneous Ethiopian nation. ${ }^{23}$ However, with over 85 ethnic groups, nation-state building was a daunting task, in spite of various efforts such as Emperor Haile Selassie's pursuits to bring together these multiethnic, multilingual, and multicultural groups.

As a reaction to this, the post-1991 federal arrangement in Ethiopia recognized Ethiopia's ethnic diversity. Although the FDRE Constitution aims to promote unity in diversity, the reality in contemporary Ethiopia depicts the opposite direction of aggravating ethnic tension and hostilities thereby jeopardizing the constitutional aims and promises. Currently, there is a growing fear concerning national unity and the question of recognition of new ethnic groups in different parts of the country.

The critical question then is how to achieve national integration in Ethiopia and therefore create a sense of shared national (Ethiopian) identity amongst the various groups that make up the Ethiopian state. The ideas of federalism have been suggested and also implemented after the demise of the Derg régime. Many Ethiopians have now come to the conclusion that in order to promote unity at different levels of government, there is the need to forge and recognize the existing diversities at different levels of government. All ethnic groups should be represented equitably in Ethiopia in general and in regional states in particular. Thus, the issue of how best to resolve the question of promoting unity in diversity requires utmost attention.

\section{Competing Claims for Ethnic and Territorial Federalism in Ethiopia}

\subsection{The arguments against and in favour of Ethiopia's ethnic federalism}

Elazar defines federalism as the advocacy of multi-tiered government combining elements of 'shared-rule' and 'self-rule'. ${ }^{24}$ It is based on the presumed value of achieving both unity and diversity by accommodating,

${ }^{23}$ C. V. Beken (2012), Unity in Diversity-Federalism as a Mechanism to Accommodate Ethnic Diversity: the case of Ethiopia, Berlin: Deutsche Nationalbibiliothek.

${ }^{24}$ D. Elazar (1987), Exploring Federalism, Tuscaloosa, AL: University of Alabama Press. 
preserving and promoting distinct identities within a larger political union. ${ }^{25}$ In this context, federalism as a political concept has grown in importance as a means of peacefully reconciling the principles of unity and diversity, which are typically found in multi-national federations. Anderson argued that "federalism seems suited to democracies with large populations or territories with highly diverse populations that are regionally concentrated". ${ }^{26}$ Various politicians and political scientists claim that federalism is one of the most effective means to solve the ethnic conflicts in multinational societies.

According to Markakis, "Ethiopian ethnolinguistic federalism was designed to address the nationality question". ${ }^{27}$ The ruling party (EPRDF) had publicly stated that ethnic federalism is the only way to address or eliminate the assimilationist or marginalization policies of previous regimes, as well as the unequal distribution of the country's economic and political resources and the denial of nations, nationalities, and peoples' rights to govern themselves through their own leaders and age-old political and legal institutions.

Alem and Tesfaye argue that multicultural federalism is a necessity and a positive innovation for Ethiopia in resolving conflicts by allowing various ethnic communities to control regions of the country where they are the majority while respecting basic minority rights. ${ }^{28}$ Both Alem and Tesfaye believe that ethnic-federalism has preserved unity and the territorial integrity in Ethiopia while fully recognizing the principle of ethnic equality.

However, there are arguments against this view. For example, Aalen, Tesfaye, Abbink, Mohammed, Kymlicka, Ottaway, Vestal, Walle and Huntington argue that the introduction of ethnic federalism in Ethiopia is the main cause of ethnic conflicts and tensions. ${ }^{29}$ They consider ethnic

${ }^{25}$ Ibid.

${ }^{26}$ G. Anderson (2008), Federalism: An Introduction, Oxford: University Press.

${ }^{27}$ Markakis, supra note 21.

${ }^{28}$ Alem Habtu (2010), Ethiopian Federalism: Principle, Process and Practice, ed. Prepared for the 5th International Conference on Federalism. Addis Ababa: Addis Ababa University Press. See also Tesfaye Habisso (2010), 'Multiethnic

(Multinational) Federalism in Plural Societies: Does It Make a Difference?' Retrieved from:

http://www.aigaforum.com/articles/Multiethnic_federalism.pdf

Accessed on 03/18/2020.

${ }^{29}$ E. Keller (1998), 'Regime change and ethno-regionalism in Ethiopia: The case of Oromo' in Asafa Jalata (ed.), Oromo nationalism and the Ethiopian discourse: The 
federalism as a recipe for the violent eruption of endless inter-communal conflicts that bears the risk of eventually leading to the disintegration or dissolution of the Ethiopian state.

In the current context, the discourse relates to which model of federalism is appropriate in Ethiopia. There are various arguments that suggest a geographical model of federalism in Ethiopia. They argue that the model of ethnically-based federalism is the source of the problem, rather than the solution. Keller, Aalen, Tesfaye, Abbink, Mohammed, Kymlicka, Ottaway, Vestal, Walle and Huntington argue that the introduction of ethnic federalism in Ethiopia is one of the main causes of ethnic conflicts or tensions. ${ }^{30}$

At regional level, one can clearly observe different positions. For example, various officials in the Amhara regional state, as well as some political parties, have called for constitutional reform, including a complete overhaul of the FDRE Constitution and a reorganization of the existing federal state structure. In this regard, the Amhara National Movement (ANM) on its official Facebook page forwarded a clear message that the

search for freedom and democracy, Lawrenceville New Jersey: The Red Sea Press, pp. 109-124.

Aalen (2002), Ethnic-federalism in a Dominant Party State: The Ethiopian Experience 1991-2000, Bergen: Chr. Michelsen Institute.

Tesfaye Habiso, supra note 28.

Abbink (1997), 'Ethnicity and Constitutionalism in Contemporary Ethiopia', Journal of African Law, 41:2, pp. 159-174.

Mohammed Hassen (1999), 'Ethiopia: Missed opportunities for peaceful democratic process' in Kidane Mengisteab and Daddieh, Cyril ed., State building and democratisation in Africa. Westport: Praeger.

Kymlicka in D. Turton (2006) ed., Ethnic Federalism: The Ethiopian Experience in Comparative Perspective, James Currey Ltd. Oxford.

Ottaway (1994), Democratization and ethnic nationalism: African and Eastern European Experience, Washington DC: Overseas Development Council.

Ottaway (1995), 'The Ethiopian transition: democratization or new authoritarianism', Northeast African Studies 2, pp. 64-84.

Vestal (1999), Ethiopia: a post-cold war African state, Westport: Praeger.

Walle (1997), 'Ethiopia: the pitfalls of ethnic federalism' in Agbango, G. (ed.) Issues and trends in contemporary African politics, New York: Peter Lang.

Huntington (1993b), 'Political Development in Ethiopia: A Peasant-based

Dominant-Party Democracy', Report to USAID/Ethiopia on consultation with the

Constitutional Commission, March 28 to April 1, 1993, pp., 14-16.

${ }^{30}$ See the sources in note 29 above. 
FDRE Constitution must be revised or amended. ${ }^{31}$ ANM' slogan that reads 'it is not my constitution' ${ }^{32}$ illustrates this view.

Mr. Yessuf Ibrahim, vice-chairman of ANM, stated that "We do not consider an ethnically constituted political organization to be an organization that has a philosophical foundation. We do not believe that ethnic and religious-based politics should be the ultimate goal for Ethiopia". ${ }^{33}$ Yessuf's statement makes it apparent that, while the ANM is an ethnic-based party, ethnic and religious parties have been and continue to be a threat to national unity in the country.

Yessuf therefore called for a constitutional amendment to address this problem in a sustainable manner. Yessuf explicitly articulated that one of the main reasons for the establishment of the ANM was the continued action undertaken during the TPLF-led EPRDF regime against the Amhara ethnic groups in various parts of the country. He also underlined that although ANM was compelled to form a party based on ethnicity due to the problems that preceded its formation, ethnic-based parties are not long-lasting solutions to foster national unity.

Apart from identity-based political parties, most of the competing political parties in Ethiopia, such as the Ethiopian Citizens for Social Justice, the All Ethiopian Unity Organization, the Balderas for True Democracy, the Ethiopian Democratic Union, and the Ethiopian National Unity Party, etc., recognize that while the federalism system is important to Ethiopia, it needs to be improved because the current Ethiopian federalism is solely structured by ethno-linguistic criteria. ${ }^{34}$ On the other hand, the TPLF in the Tigray regional state insists that amendment and revision of the FDRE Constitution and re-arrangement of the existing federal state structure is unnecessary. ${ }^{35}$ Supporters of this view consider any attempt to amend or revise the current FDRE Constitution and promote national unity as a unitary (ahadawi) and anti-federalist. $^{36}$

\footnotetext{
${ }^{31}$ Accessed on the Amhara National Movement official Facebook page on April 29, 2020.

${ }^{32}$ Ibid.

${ }^{33}$ Vice-chairman of ANM Ibrahim, Y. (2021, April 14). Walta TV free ideas discussion and debate program. (S. Bayedeferese, Interviewer).

${ }^{34}$ For further information, you can refer to each party's manifesto.

${ }^{35}$ For example, Dimtsi Weyane Television, 6 September (2019),

${ }^{36}$ For example, Dimtsi Weyane Television, 9 July (2020), TPLF statement.
} 
Contrary to the verbal expressions of loyalty to the Constitution however, the 2020 regional election held in the Tigray regional state was conducted in an apparent violation of the FDRE Constitution. Article 102(1) of the FDRE Constitution states that "a National Election Board independent of any influence should be constituted to conduct, in an impartial manner, free and fair elections in federal and state constituencies." Such acts of violating the Constitution, and the claim of upholding the Constitution as its 'custodian' are clearly contradictory.

\subsection{The need for synthesis in perspectives}

Various scholars agree that federalism is a dynamic system that can be modified based on the existing circumstances of the particular state. In fact, the majority of the countries that have adopted the federal system have a mixed model of federalism. In the mixed model of federalism, some regions are organized geographically, while others are organized by language and ethnicity with due attention to their geographic adjacency and administrative efficiency. This type of federal system configuration is called a mixed model federal system. It combines geographic and ethno-linguistic elements.

Art 46(2) of the FDRE Constitution stipulates that "States shall be delimited on the basis of settlement patterns, language, identity, and consent of the concerned people." This provision embodies ethno-linguistic and geographical elements. For example, settlement patterns, as one of the criteria for delineating constituent units shows some parameters for demarcating constituent units based on geographic location.

However, the practical arrangement on the ground shows that the structure of the Ethiopian federal system is purely ethno-linguistic. Apparently, the nine regions were established solely on the basis of ethnicity, including the newly established additional regional states. Although the names of some regional state names are not associated with a specific ethnic group, all regional states in the country are structured based on ethnicity.

In the Ethiopian context, it is recognizable that ethnic federalism is one of the key causes of ethnic conflicts. As the current Ethiopian federal system has been structured solely on the basis of ethnicity, the realities clearly show that it creates ethnic conflicts rather than resolving conflicts in different parts of the country in general and in regional states in particular. At this point, it may be argued that creating constituent units solely along ethnic lines has exacerbated ethnic conflicts in the country.

This clearly proves the structural problem in the Ethiopian federal system which has the potential to exacerbate further ethnic tensions. This calls for the inclusion of geographic elements in the existing structure of Ethiopia's 
federal system. I argue that the combination of ethnicity and geography can help to reduce some of the ethnic conflicts. Indeed, many scholars argue that federalism is not a universal solution to every human-made problem, and it certainly cannot be a problem in and of itself for every problem.

The assumption promoted by various groups and individuals as if the federal system enshrined in the FDRE Constitution cannot be reformed is incompatible with the nature of federalism. In fact, the cornerstone of this state of mind is that some groups consider themselves as the sole defenders of the country's federal system. It is vital to note that this notion is incorrect because federalism is a government structure that may be reformed depending on the circumstances. The other extreme of considering Ethiopia's federal system as completely flawed thereby suggesting the entire abrogation of the FDRE Constitution is also problematic.

Both extreme perspectives are currently contributing towards the exacerbation rather than a solution to Ethiopia's problems. In spite of its limitations, the post-1991 Ethiopian federal political system has -to some extent- brought ethno-cultural justice to historically marginalized minority ethnic groups in the country, particularly in the areas of language, culture, and local self-government. Hence, I argue that rather than completely dismantling the existing federal system's structure, it is essential to consider a synthesis that can reconcile the two perspectives.

Under Ethiopia's current realities, it would be naive to expect that entirely dismantling and restructuring the existing federal structure would permanently fix problems. To this effect, without completely dismantling the present federal system, it is vital to identify and fill gaps in the existing federal system. As Michael Stein noted, "federal governments and federal constitutions do not grow simply by accident." ${ }^{37}$ And, his argument clearly demonstrates that federalism is a government system that can be modified based on the prevailing circumstances.

\section{Federalism and Ethnic Party Politics in Ethiopia: Some Observations}

Numerous scholars have proposed various definitions of the concept of a political party. For example, Appadorai defines a political party as a more or less organized group of citizens who act as a political unit, with distinct aims

${ }^{37}$ Michael B. Stein (1968), 'Federal Political Systems and Federal Societies', World Politics, 20, pp. 721-747 Doi:10.2307/2009691 
and opinions on a state's political issues, and who seek to control the government as a political unit. ${ }^{38}$ According to Adeyemi, political parties are associations formally organized with the explicit and declared purpose of acquiring or maintaining legal control over the personnel and policies of the government of a sovereign state, either individually or in coalition or in electoral competition with other similar associations. ${ }^{39}$

Sartori indicates that parties are the central, intermediate, and intermediary structures between society and government, and as such, they must strive to serve the 'public interest' or the common good and 'organize the chaotic public will. ${ }^{40}$ Similarly, Neumann stated that a political party is "the great intermediary that links social forces and ideologies to official governmental institutions and relates them to political action within the larger political community". ${ }^{41}$

Political parties, according to Burgess, are vehicles and instruments of organized, vested interests that express specific values, beliefs, and aspirations. They are partisans with particular cleavage patterns and vested interests. ${ }^{42}$ Under such settings, the role of regional parties in expressing territorial diversities is part and parcel of an asymmetrical party system. ${ }^{43}$ However, this does not imply that regional political parties always disregard the country's common values and interests. They could, of course, become vehicles of diversity and unity at the same time.

In light of the scholarly explanations provided above, a political party is a group whose members act in concert in the competitive struggle for political power with the primary goal of promoting the common public good. This power should ultimately be used to further the interests of the party's members as well as the public good. Thus, as one institutional entity, political parties promote, preserve, and protect existing diversity while also

38 Arjun Apparodai (1968), The Substance of Politics, OUP, London.

39 Adeyemi in Ubani, C. (2014), 'Political Parties and National Integration: An Assessment of the Nigerian State since Independence', Covenant University Journal of Politics and International Affairs, Vol. 2, pp. 31-44.

${ }^{40}$ Giovanni Sartori (1994), Comparative Constitutional Engineering: An Inquiry into Structures, Incentives and Outcomes, New York: New York University Press, Pp. xi, 219.

${ }^{41}$ Neumann in Horowitz, D. (1985), Ethnic Groups in Conflict, California: University of California Press.

${ }^{42}$ Michael Burgess (2006), Comparative Federalism: Theory and Practice, Abingdon, Oxon: Routledge.

43 Rudolf Hrbek (Ed.) 2004, Regional Parties and Party Systems in Federal States (Baden-Baden: Nomos Verlag). 
promoting a sense of unity, particularly in federations that were founded to accommodate or manage diversity.

It means that ideologies and policies that promote a sense of unity in diversity should be viewed audaciously, both ideally and practically, by each political party, based on their own country's specific context. Political parties are considered as one of the crucial actors in multiethnic federations, promoting unity in diversity. Moreover, in any democratic political system, opposition political parties should serve as unpaid researchers in their country's political environment in order to enhance the essence of democracy and peaceful coexistence between various cleavages.

In this respect, Duchacek states that democracy and federalism are inextricably linked; federalism is the territorial dimension of democracy; and genuine competition between parties is a prerequisite for federalism. ${ }^{44}$ The structure of party systems and the role played by political parties are important determinants of functioning of federal systems. ${ }^{45}$ Watts noted that political parties and the party structure affect the degree of decentralization within federations. ${ }^{46}$ It is obvious that political parties in democratic states must serve as a guide to achieving national and subnational unity. Political parties are expected to be institutions capable of promoting regional and national unity in multiethnic states.

In the Ethiopian context, however, politicians have ignored this function although political parties are supposed to serve as a bridge between competing ethnic nationalities. This is predominantly attributable to will and political culture rather than lack of awareness. Actually, the parties and their officials are well aware that unity is supposed to serve as a channel through which the bitter and secret conspiracy thriving within the political scene can be reduced to a negligible level, if not completely eradicated from the country's political life.

It is evident that there is disagreement among scholars on the benefits and drawbacks of ethnic-based political parties. They have different perspectives on the advantages and disadvantages of ethnic-based political parties in divided societies. Several scholars, such as Reilly, Gunther and Diamond, Koeble, Becher and Basedau, Horowitz, Rabushka and Shepsle, Ishiyama,

\footnotetext{
${ }^{44}$ Ivo D. Duchacek (1970), Comparative Federalism: The Territorial Dimension of Politics, New York: Holt, Rinehart, \& Winston.

${ }^{45}$ Riker, supra note 17 , p. 129.

${ }^{46}$ Ronald Watts (2008), Comparing Federal Systems, $3^{\text {rd }}$ edition, Montreal; Kingston; London; Ithaca: McGill-Queen's University Press.
} 
and Hicken, have a negative view on ethnic-based political parties. ${ }^{47}$ Their core argument is that ethnic based-political parties can aggravate ethnic strife and threaten the stability of fledgling democracies. In support of this perspective, Ugandan President Yoweri Museveni has stated the following caveat based on his experience and observations:

I have been observing and participating in politics for the past 60 years. We have some observations. One of the problems in Uganda has been identity politics, which has caused a lot of problems. We addressed the issue, and moved from the politics of identity to the politics of interest. ${ }^{48}$

The important thing to understand from President Yoweri Museveni's speech is that ethnic-based politics contributes to the escalation of ethnic tensions by dividing party politics along ethno-cultural lines, which frequently leads to the outbreak of violent ethnic conflicts. Furthermore, ethnic-based parties can significantly raise the stakes of the political game by supporting identity-based politics, reinforcing group identities, and increasing the likelihood of ethnic conflicts. As John Ishiyama

${ }^{47}$ Benjamin Reilly (2003), "Political Engineering of Parties and Party Systems.” Paper presented at the Annual Meeting of the American Political Science Association, Philadelphia, PA.

Richard Gunther and Larry Diamond, (2003), "Types and Functions of Parties," in Larry Diamond and Richard Gunther (eds.), Political Parties and Democracy, Baltimore and London: Johns Hopkins University Press, pp. 23-4.

Thomas Koelble (1995), "Towards a Theory of Nationalism: Culture, Structure and Choice Analyses Revisited," Nationalism and Ethnic Politics, Vol. 1, No. 1, pp. 73 89.

Anika Becher and Matthias Basedau, (2008), "Promoting Peace and Democracy through Party Regulation? Ethnic Party Bans in Africa," GIGA working papers 66, Hamburg: German Institute of Global and Area Studies/Leibniz-Institut fur Globale und Regionale Studien.

Donald Horowitz (1985), Ethnic Groups in Conflict (Berkeley: University of California Press;

Alvin Rabushka and Kenneth Shepsle (1972), Politics in Plural Societies: A Theory of Democratic Instability Columbus, $\mathrm{OH}$ : Merrill.

John Ishiyama (2009), 'Do Ethnic Parties Promote Minority Ethnic Conflict?', Nationalism and Ethnic Politics, 15:1, 56-83, DOI: 10.1080/13537110802672388.

Allen Hicken (2008), 'Political engineering and party regulation in Southeast Asia' Benjamin Reilly and Per Nordlund (eds.), Political Parties in Conflict Prone Societies: Regulation, Engineering and Democratic Development, Tokyo: United Nations University Press, 2008: 69-94.

48 Uganda's President Yoweri Museveni speech at Prime Minister Abiy Ahmed's swearing-in ceremony, October 04, 2021, Addis Ababa, Ethiopia. 
demonstrated, in divided societies, ethnic parties may encourage ethnic minorities to resort to undemocratic or even violent means. ${ }^{49}$ In this respect, the ongoing violent conflict between the federal government and the TPLF substantiates President Yoweri Museveni's experience and Ishiyama's arguments.

On the other hand, Arend Lijphart, Frank S. Cohen, Sherrill Stroschein, Lilia Petkova, and Daniel N. Posner contend that ethnic parties can play a constructive role in promoting intergroup accommodation. ${ }^{50}$ They contend that the ethnification of politics does not necessarily translate into ethnic violence. They argue that ethnic parties do not produce ethnic conflict, but rather emerge as a result of it -that is, they reflect differences that already exist.

Indeed, it is an inevitable reality that in multi-ethnic federations, diversity must be recognized as a foundation for promoting unity in diversity. As a result, each of the regional political parties should do so in order to reflect their own differences, as this is important for promoting regional unity. Regional unity entails recognizing all of a nation's constituent parts, attending to their needs, and making sacrifices in the national interest. This means that political parties can achieve unity in diversity by recognizing and promoting the various ethnic nationalities found within their borders.

As stated above, national or regional unity in multiethnic federal states will be achieved only when different ethnic cleavages are recognized and fairly represented within various institutions. With this assumption, the FDRE Constitution aims to promote unity in diversity, but the reality on the ground in the contemporary Ethiopian context is not in tandem with the

49 John Ishiyama (2009), 'Do Ethnic Parties Promote Minority Ethnic Conflict?', Nationalism and Ethnic Politics, 15:1, 56-83, DOI: 10.1080/13537110802672388. p. 58.

${ }^{50}$ Arend Lijphart (1974), The Politics of Accommodation: Pluralism and Democracy in the Netherlands, 2nd ed., Berkeley: University of California Press.

Frank S. Cohen (1997), 'Proportional versus Majoritarian Ethnic Conflict Management in Democracies', Comparative Political Studies, Vol. 30, No. 5, pp. 607-30, p. 613.

Sherrill Stroschein (2001), 'Measuring Ethnic Party Success in Romania, Slovakia and Ukraine', Problems of Post-Communism, Vol. 4, No. 1, pp. 59-69.

Lilia Petkova (2002), 'The Ethnic Turks in Bulgaria: Social Integration and Impact on Bulgarian-Turkish Relations, 1947-2000', Global Review of Ethnopolitics, Vol. 1, No. 1, pp. 36-55, 52.

Daniel N. Posner (2004), 'Measuring Ethnic Fractionalization in Africa', American Journal of Political Science, Vol. 48, No. 4, pp. 849-63. 
activities of various politicians, thereby jeopardizing the constitutionally entrenched spirit of promoting unity in diversity within the country in general and regional states in particular.

One important issue undermining the proper operation of contemporary Ethiopian federalism is the lack of a clear demarcation between the governmental structure and party activity. Various individuals or groups in Ethiopia have a tendency to align a federal system with a political party structure. However, it is incorrect to assume that federalism and political party organization in a democratic system are identical. This is because the federal system is a government structure, not a political party structure. Working as a mix of government and political party gives rise to the perception that whenever political parties are in danger, the federal system is also in jeopardy. This is not mere perception but can also entail adverse consequences. Thus, democratic systems separate the functions of political parties and the tasks of the government.

Another key factor that has shaped Ethiopia's federal system is that political parties in different regional states have been organized based on ethnicity. Ethnic identity plays an important role in the creation and differentiation of parties in post-1991 Ethiopia. For a variety of reasons, only a few Ethiopian parties have sought to distinguish themselves through policy platforms; and ethno-cultural identities have been a major, if not the only, factor in differentiating parties within the country. This contributes to the ethno-regional polarization in the country's political system. In the post-1991 Ethiopian political setting, debates about policy have been essentially nonexistent. Election campaigns have been conducted almost entirely on the basis of ethno-cultural appeals for support from electoral constituencies.

Ethnic-based political parties have maintained power at the federal and regional state levels in Ethiopia since the country's adoption of the federal system. This scenario would gradually pave the way for nationalist extremism. In Ethiopia, ethnic-based political parties, rather than the federal system's structure, serve as the base for the rise of elevated ethnic nationalism. Political parties organized by ethnic groups in Ethiopia are clearly the major causes and sources of ethnic conflict. It is crucial to underline that the rise of ethnically based political parties is a greater source of ethnic conflict than the federal system per se (even if there is a reciprocal causal relationship between the two).

Indeed there is the need for focus on policies and the competence and integrity of individual candidates rather than fixations on the ethnic identity. In this regard, there is some improvement following the establishment of the Prosperity Party although much has yet to be done. Prosperity Party is now 
accommodating various competing parties into the executive branch of government. Yet, it should not be underestimated that the ethnic mindset established over the last 27 years can disrupt upcoming smooth and peaceful democratic political transition.

The political vision in the country as a whole, and in the regional states in particular, is to strengthen unity. Unfortunately, however, elected officials usually sit back and focus solely on how to recoup political power. Political discussions and promises about national and regional unity usually die immediately after each election. ${ }^{51}$ Hence, it appears that all of the positive promises and hopes made during elections are only intended to generate votes rather than promote ethnic unity. The key factor behind this challenge is overemphasis on ethnic identity. Therefore, it can be argued that ethnic-based political parties in Ethiopia are not appropriately promoting unity in diversity in various parts of the country.

\section{Inter-Regional Boundary Disputes and Contentious Land- Ownership Claims}

Boundary disputes have been a common problem in most regional states since the establishment of Ethiopia's current federal system. In this regard, Alene Agegnehu and Worku Dibu note that an artificial demarcation of regional state boundaries primarily based on ethnicity generates violent conflicts among ethnic groups in the country. Zerihun Berhane and Samuel Tefera, likewise noted that the system is enhancing conflicts. ${ }^{52}$ Since the

${ }^{51}$ FGDs with various communities, 2020.

52 Alene Agegnehu and Worku Dibu (2016), 'Does Ethnic-federalism Exacerbating or Reducing Conflicts? The Ethiopian Federal Experiences', International Journal of Emerging Trends in Science and Technology, 4838-4845.

Zerihun Berhane and Samuel Tefera. (2018), 'Does Federalism Reduce Ethnic Conflict? Evidence from the Ethiopian Experience', Ethiopian Journal of the Social Sciences and Humanities, pp. 105-131.

See also:

Yonatan Tesfaye (2016), infra note 80

Demissie F. (2019), infra note 80

Berhanu Gutema Balcha (2006), infra note 80

Fisseha Y. (2016), Conceptualizations and Impacts of Multiculturalism in the Ethiopian Education System (PhD dissertation),

Asnake K. (2013), infra note 58

Muhabie M. (2015), 'Ethnic Federalism: A Means for Managing or a Triggering Factor for Ethnic Conflicts in Ethiopia', Social Sciences, pp. 94-105. 
establishment of the federal system, examples regarding the main sources of boundary and land-based disputes in Ethiopia are highlighted in Sections 6.1 and 6.2 below.

\subsection{Metekel, Raya, and Wolkait}

One of the major factors of boundary and land-based disputes is agitated by some political elites. These disputes are caused by the demands of communities that seek specific territories and due to the desire of ethnic groups to be incorporated into another regional state. Ethnic groups and areas that were not part of Tigray before 1991 were incorporated into Tigray Regional State while TPLF-dominated EPRDF was in power. In this regard, the ANM announced that areas, such as Metekel, Raya, and Wolkait, were part of administrative units that currently constitute the Amhara regional state. ${ }^{53} \mathrm{It}$, in effect, demands that the aforementioned territories should be returned to and administered by the Amhara regional state..$^{54}$

The central essence of this claim is that these specific territories do not belong to Benishangul Gumuz regional state and Tigray regional state historically or based on the pre-1991 administrative structure. For example, in the previous system, the Metekel Zone in the current Benishangul Gumuz region was organized into the Administrative Region of Gojjam in Amharic Gojjam Kefel Hager. There are views that the Amhara and other nonindigenous nationalities in the Benishangul Gumuz regional territories are migrant settlers who should not own or lay claim to land or political rights in any part of their communities, a claim that the non-indigenous nationalities disagree with. The resulting tension created by the opposing perceptions of land ownership among members of these groups is at the root of the violent conflicts experienced in the region, especially since 1991.

Although Metekel Zone was previously administered by Gojjam Administrative Region, it must be noted that Gojjam -in pre-1991 Ethiopiarepresented a specific geographic area or location rather than a single ethnic group. The logical conclusion that emerges from this premise renders Metekel the homeland of all Metekel residents. Metekel Zone is thus the homeland of all Ethiopians who live in Metekel, including the Shinasha, Gumuz, Agew, Amhara, Oromo, and others. However, this is not reflected in ANM or other groups who make exclusive claims.

\footnotetext{
${ }^{53}$ Accessed on the Amhara National Movement official Facebook page on April 29, 2020.

${ }^{54}$ Ibid.
} 
It should be argued at this point that Metekel's fate should be decided solely by its residents. Residents of Metekel have full constitutional right to relocate to the Amhara region or to continue in the Benishangul Gumuz region. If any group desires to join the Amhara region, the demand is constitutional. In this regard, in order to fulfill the request, the concerned authorities must arrange a referendum to determine Metekel's fate once and for all because the FDRE Constitution declares that nations, nationalities, and people have the right to self-government. Short of such perspectives, the claims of ANM and other groups becomes implausible as long as it excludes other indigenous ethnic groups.

These issues do not only relate to ethnic identity, but also involve claims on land. The land ownership questions raised by various political elites are among the major causes of violent ethnic conflicts. This includes the recent violent ethnic conflict between the Gumuz and other ethnic groups residing in the region in general and the Metekel Zone in particular.

Another case, in addition to Metekel of Benishangul Gumuz, is the question of Wolkait-Tsegede and Raya land ownership. According to historical sources, Welkait and Raya were part of Semien Wogera Awraja under the Gondar Administrative Region (Gondar Kefel Hager) and Wollo Administrative Region (Wollo Kefel Hager), respectively. It is evident that since 1991, the areas of Welkait, Tsegede, Tilimt, Humera, and Raya were delineated as part of the Tigray regional state.

However, currently, various bodies are claiming that Wolkait-Tsegede and Raya are Amhara. For instance, the 'Welkait Amhara identity question committee' that was organized in Amhara regional state demanded that their land and people should be included in the Amhara region, with whom they identify themselves culturally, ethnically, and linguistically. Therefore, the committee argues that the above-mentioned territories (i.e., Wolkait-Tsegede and Raya) should be returned to and be administered by the Amhara regional state.

The essence of this claim is that (based on the pre-1991 administrative structure) these specific territories do not belong to Tigray regional state. The Raya and Wolkait-Tsegede questions raised by various political elites, have become a playground for different political and social groups. This has fueled inter-regional boundary conflict between the Tigray and Amhara regions thereby undermining nation-building pursuits in Ethiopia. 


\subsection{The boundary dispute between BGRS and the Oromia regional state}

Another major tension and competing claims between regional states relate to the constitutions of some regional states that claim boundary or land ownership that is incompatible with the reality on the ground. For example, under Art 2(1) of the first Oromia Regional State Constitution of 1995, there was no statement which indicated that Oromia's western part shares border with the Sudan. However, Art 2(1) of the revised 2001 Oromia Regional State Constitution, expressly stipulates that the region shares a border with Sudan to the west. However, Oromia rather shares a border with the Gambella regional state in the west, but this does not imply that the region has a border with Sudan. This constitutional controversy has contributed to the contention between the two regional states, particularly around their boundary areas.

Another challenge in the relationship between these two regional states in the Ethiopian federal state structure is the boundary dispute between BGRS and the Oromia regional state, which began in the formative years. For instance, during the 1991-1994 transitional government, a boundary dispute erupted between the BG and the Oromia regional state in the Beggi and Tongo areas. As indicated by Asnake by citing Atieb (1973) and Rasheed (1995), BGRS's claim to incorporate Beggi areas into BGRS is based on two fundamental grounds. First, the territory was previously ruled by Sheik Khojele of Assosa. Second, the Mao and Komo ethnic groups, who were assigned to BGRS, were the earlier inhabitants of the area. ${ }^{55}$

In this regard, the transitional government issued an official letter in December 1995, taking into account the unanimous agreement of both BGRS and Oromia regional state boundary demarcation committee representatives, and accordingly demarcating all 88 Kebeles of Beggi Woreda into the BGRS administration. ${ }^{56}$ However, a few months later, in order to permanently resolve the boundary dispute between the Oromia regional state and the BGRS, particularly in Beggi Woreda, the transitional government organized a referendum. As a result, the majority of voters in Beggi Woreda decided to leave the BGRS administration and join the Oromia regional state administration. In this context, official evidence

${ }^{55}$ Asnake K., infra note 58.

${ }^{56}$ Muluneh Kassa (2021), The Praxis of Unity in Diversity at Sub-National Governments in Ethiopia: An Empirical Analysis of Benishangul-Gumuz Regional State Practice, Dodo Books Indian Ocean Ltd., member of OmniScriptum S.R.L Publishing group: Lap LAMBERT Academic Publishing. 
indicates that the total number of Kebeles in Beggi Woreda during the referendum was $88 .{ }^{57}$

The referendum indisputably altered the administrative maps of both the BGRS and the Oromia regional state. Asnake notes that the referendum resulted in changes to the administrative map of BGRS, ${ }^{58}$ but it has also resulted in changes to the administrative map of Oromia regional state. At this point, Asnake and others should have made a distinction between the BGRS map and their reference to the referendum held in Beggi Woreda in $1995 .{ }^{59}$ Their statements that the BGRS no longer shares a border with the Gambella region contradict the facts on the ground.

All 88 Kebeles of Beggi Woreda do not share a boundary with the Gambella regional state, as one might expect. Oromia regional state shares a boundary with the Gambella regional state in other Woredas of the region rather than in Beggi Woreda Kebeles. Second, the BGRS shares boundary with the Etange Special Woreda of Gambella Regional State, specifically in Kusay, Laki, Myti, Shumty, and Shrma Kebeles of Mao Komo Special Woreda. ${ }^{60}$ Based on this reality, Article 3 of both the 1996 Gambella regional state Constitution and the 2002 Revised Gambella Regional State Constitution explicitly states that Gambella regional state shares a boundary with BGRS in the north. Third, existing regional administrative maps issued by unknown organizations have not taken into account the reality on the ground in BGRS and other regional states of the country. ${ }^{61}$

Fourth, as stated above, there is no statement in Art 2(1) of the first Oromia Regional State Constitution of 1995 that describes the issues of Oromia's border sharing with Sudan in the region's western part although the revised 2001 Oromia Regional State Constitution explicitly stated that the region shares a border with Sudan to the west. ${ }^{62}$

Therefore, it is clear that the revised 2001 Oromia Regional State Constitution does not take the empirical reality on the ground into account, and as a result, this constitutional controversy has caused tension between both regional states, particularly near the regions' boundaries. An interview

\footnotetext{
${ }^{57}$ Ibid.

${ }^{58}$ Asnake Kefale (2013), Federalism and Ethnic Conflict in Ethiopia: A Comparative Study of the Somali and Benishangul-Gumuz Regions, New York: Routledge.

${ }^{59}$ Ibid.

${ }^{60}$ Muluneh Kassa, supra note 56.

${ }^{61}$ Ibid.

${ }^{62}$ Ibid.
} 
with a higher official in the region indicates that the current Mao Komo special Woreda was established on this basis to strengthen the selfadministration rights of Mao and Komo and the people in the region. Moreover, the respondent also stated that at the end of the referendum, many of the Mao people who identified themselves as black Oromo voted for Oromia and settled there. ${ }^{63}$ In this regard, there are currently over 50,000 Mao ethnic group members in the Oromia region, particularly in Beggi, Anefilo, Konedala, and Gidami Woredas, who have been assimilated by the Oromo and are going to lose their identities. ${ }^{64}$

The source of the boundary dispute between these two regional states is essentially complicated by the territorial size conceived by the OLF, which is larger than the Oromia regional state's current territorial dimension ${ }^{65}$ Prior to the establishment of the current federal state structure, the Kamashi Gumuz, Mao, Komo, and Assosa areas were administratively organized under the Oromo-dominated former Wollega province due to their proximity and strong socioeconomic ties with the Oromos. ${ }^{66}$ The continued migration of Oromo rural farmers to the fertile lowlands of BGRS had influenced the referendum result, because demography is important in winning the political game. ${ }^{67}$

According to the 2017 report by the BGRS Security and Administration Bureau, boundary demarcation issues between the BGRS and the Oromia regional state have been undermining the peaceful coexistence of both regional states around some neighborhoods of Kebeles. ${ }^{68}$ For example, the demand of the Oromia regional state's Gidam Woreda for Kusaye and other Kebeles of BGRS's Mao Komo Special Woreda has recently affected the stability of the neighboring Kebeles of both regional states. ${ }^{69}$ As a result, at the conference held in Dembi Dolo town in November 2017, both regional states agreed to form a joint committee to find a long-lasting solution to this problem. ${ }^{70}$

According to the (2017) report of the joint technical committee, there are three main issues concerning Gidam Woreda of Oromia regional state's

\footnotetext{
${ }^{63}$ Ibid.

${ }^{64}$ Ibid.

${ }^{65}$ Asnake K., supra note 58

${ }^{66}$ Ibid.

${ }^{67}$ Muluneh K., supra note 56.

${ }^{68}$ Ibid.

${ }^{69}$ Ibid.

${ }^{70}$ Ibid.
} 
claim to incorporate Kusaye Kebele under the Oromia regional state administration. These issues are: (i) what is the ethnic identity of the Kusaye Kebele people? (ii) Which city, Woreda and the region of Kusaye Kebele, is the closest geographically? (iii) Where is the market center for the people of Kusaye Kebele? The two main counterclaims on the side of the BGRS Mao Komo Special Woreda are: (i) whether the people of Kusaye Kebele benefit under the administration of the Oromia regional state or the BGRS; and (ii) whether there are any current issues affecting the people of Kusaye Kebele under the administration of the BGRS.

Based on the claims indicated above, the Oromia regional state intends to hold a referendum to decide the fate of Kusaye Kebele. The BGRS, on the other hand, claims that during the transitional period, the federal government of Ethiopia has explicitly decided that Kusaye Kebele should be demarcated and administered by the BGRS. ${ }^{71}$ In this regard, the argument of BGRS officials was that both regional states have agreed and signed (in Tahsas 1986 E.C/ December 1993) that Kusaye Kebele would be demarcated under BGRS administration during the transitional period of Ethiopia. ${ }^{72}$

Most BGRS higher officials relate the situation with the tacit continuation of the OLF's historical territorial aspiration and, as a result, some Oromia political actors aspire an international border with Sudan in the west. ${ }^{73}$ In light of the current recurrent migration of Oromo to Kusaye and other areas of the BGRS, holding a referendum to decide the fate of Kusaye Kebele is considered (by the BGRS) as improper.

Territorial disputes between the BGRS and the Oromia regional state erupted around the Darro-Dimitu and Tolle localities, in addition to the Beggi area. ${ }^{74}$ Empirical evidence indicates that the Oromo and the Gumuz coexisted in the Darro-Dimitu and Tolle localities. However, since the adoption of the current federal state structure, both the Oromo and Gumuz ethnic groups of the areas have expressed claims to incorporate these areas into their respective regional states.

For example, the core premise of Gumuz's claim was that they were earlier inhabitants of the areas. On the other hand, Oromo residents argue that the assignment of Darro-Dimtu and its environs to the Oromia region

\footnotetext{
${ }^{71}$ Ibid.

72 Ibid.

${ }^{73}$ Ibid.

${ }^{74}$ Asnake K., supra note 58
} 
was acceptable because the majority of the residents are Oromo. ${ }^{75}$ They also state that the contested Kebeles were previously organized under the Oromodominated Wollega province. ${ }^{76}$

This shows that the situation has become more complicated as a result of the conflicting interests of the political elites in both regions in resolving the issue. For example, the Oromo political elites anticipate a referendum to solve the problem, whereas the Gumuz political elites seek a political decision by the federal government in light of their prior history rather than a referendum. ${ }^{77}$ This is because indigenous people have historically been pushed out of their territories by neighboring ethnic groups. ${ }^{78}$

The earlier lopsided relationship established between the region's indigenous peoples and the ethnic groups of neighboring regional states (as represented by the actions of former political elites) was a major factor in the escalation of such friction and tension around the border areas of both regional states. For example, until the Derg regime, the indigenous ethnic groups of Benishangul Gumuz state were segregated by the neighboring dominant ethnic group's political elites. ${ }^{79}$

This friction and tension was exacerbated further by the widespread and continuous migration of neighboring ethnic groups within the BGRS. The Gumuz people's dispersed settlement pattern stretching from the former Wollega province in the south to the northwestern (Metema and Qwara) parts of the former Gonder province has exacerbated the friction and tension in the inter-regional boundary demarcation. It is to be noted that according to Article 46 of the FDRE Constitution, regional state boundaries are determined primarily on the basis of ethnic identity and ethnic groups' residential territories.

Indeed, as indicated above, numerous scholars contend that the institutionalization of federalism solely on the basis of ethno-linguistic criteria has resulted in the emergence of various boundary disputes among Ethiopia's regional states. ${ }^{80}$ At the same time, this has an impact on the

\footnotetext{
75 Ibid.

${ }^{76}$ Ibid.

${ }^{77}$ Ibid.

78 See for example, Mebratie (2005) \& Pankhurst (1997), in Mesfin Gebremichael (2011), Federalism and Conflict Management in Ethiopia: Case Study of Benishangul-Gumuz Regional State (PhD thesis), Bradford: University of Bradford.

${ }^{79}$ Ibid.

${ }^{80}$ See for example,
} 
relationships between different ethnic groups that have lived peacefully in ethnically mixed villages and localities for centuries. ${ }^{81}$ Furthermore, as Asnake argues, the boundary dispute has become complicated when ethnic entrepreneurs seek to use intra-federal boundaries for the advancement of the 'interests' of their ethnic groups at the expense of their neighbors. ${ }^{82}$ In this respect, the BGRS is one of the regions characterized by proxy ethnic political games played by the political actors of neighboring regional states. $^{83}$

\section{Examining the Experience of Ethnic Minority Management at the State Level: A Brief Overview}

According to historical evidence, ethno-linguistic diversity is viewed as a burden in African countries. However, diversity as a social fact has always existed in the world-at-large, but it becomes a 'problem' mainly when it exists within the territory of a state. ${ }^{84}$ There are two main reasons why diversity within the state territory becomes a problem. One, when social, cultural, or racial differences become the basis of group inequality. ${ }^{85}$ Two, when different groups perceive one another as inferiors or superiors. ${ }^{86}$ Hence, in the current political dynamics, managing diversity has emerged as the foremost overarching and urgent issue in ethnically heterogeneous states.

Yonatan T. (2016), 'The Original Sin of Ethiopian Federalism', Ethno politics, vol. 16, pp. 232-245, DOI: 10.1080/17449057.2016.1254410.

Zerihun B. and Samuel T. (2018), 'Does Federalism Reduce Ethnic Conflict?

Evidence from the Ethiopian Experience', Ethiopian Journal of the Social Sciences and Humanities, pp. 105-131.

Demissie F. (2019), Ethnic Decentralization and Negotiating Statehood in Urban Ethiopia: A Case Study of Adama and Hawassa Cities (PhD dissertation),

Berhanu Gutema Balcha (2006), Restructuring State and Society: Ethnic Federalism in Ethiopia(PhD thesis), Aalborg, Denmark: Aalborg University.

Fisseha Y. (2016), Conceptualizations and Impacts of Multiculturalism in the Ethiopian Education System (PhD dissertation)

${ }^{81}$ Asnake K., supra note 58

82 Ibid.

${ }^{83}$ Muluneh K., supra note 56.

${ }^{84}$ A. Majeed, J. Isawa et al (2008), 'Building on and Accommodating Diversities', Ronald L. Watts and Rupak Chattopadhyay (eds.), Unity in Diversity Learning from Each Other (Volume 1) Building on and Accommodating Diversities, pp. 3-20, New Delhi: Forum of Federations.

${ }^{85}$ Ibid.

${ }^{86}$ Ibid. 
There are different methods that can be used to manage ethnic diversity in ethnically heterogeneous states. For instance, the containment approach, the assimilationist strategy, power sharing, providing autonomy, representation, and recognition. In fact, both containment and assimilationist approaches are pernicious and awkward strategies to manage diversity, particularly in plural states.

In Ethiopia, ethnic-federalism as an institutional arrangement has been adopted primarily to address the challenges of ethnic diversity. The regional states are also responsible for recognizing and promoting the existing diversity based on their own local context. When seeking better constitutional accommodation within a multinational state, the aspirations of sub-state national societies touch upon both legal and political elements. ${ }^{87}$ One example of the former is the amendment (or the re-interpretation) of the formal constitution, whereas the political elements can be identified in the refinement of constitutional conventions, practices, and principles, or in the political culture and value system informing the given constitution. ${ }^{88}$

There are various mechanisms that can be used to manage ethnic diversity. The major areas to which sub-state national societies aspire regarding minority management are providing regional autonomy or constitutional devolution of power, constitutional recognition of diversity, power sharing and consociationalism, and representation and participation in various political institutions ${ }^{89}$ It is obvious that in Ethiopia there is a problem of ethnic minority management at the regional level. In all regions, the extent of ethnic diversity varies from region to region. The problem of the treatment of regional ethnic minorities is evident in all regions. Of course, the degree of the problem may vary from region to region, but the problem is visible in most regional states.

Currently, each regional state in Ethiopia has its own separate constitution. However, almost all regional state constitutions have limitations on recognizing non-owner nationalities within each region. The constitutions of regional states are restrictive in terms of dealing with ethnolinguistic diversity. For example, this can be observed from the names of the

\footnotetext{
${ }^{87}$ S. Tierney (2004), Constitutional Law and National Pluralism, Oxford \& New York: Oxford University Press.

${ }^{88}$ Ibid.

${ }^{89}$ Fathe M. and Muluneh K. (2021), 'Protection of indigenous minority voting rights in the Ethiopian electoral system: The case of Harari National Assembly', Journal of Social and Administrative Sciences, Vol. 8, pp. 91-110.

Doi: http://dx.doi.org/10.1453/jsas.v8i3.2236.
} 
regions. In fact, the existing constitutions of the regions were developed by the federal government. Even though the federal constitution expressly grants regional states the right to draft state constitutions, the current state constitutions were drafted and adopted with the active participation of the federal government at the time.

In some regional states, the regional state constitution expressly divides Ethiopian citizens into indigenous and non-indigenous groups. In all regional states, the constitutions explicitly recognize some ethnic groups as the owners of the region by excluding other minority ethnic groups. This generally indicates that diversity management in contemporary Ethiopia is a serious problem in the regions. Some examples can be highlighted with regard to the treatment of ethnic minorities in some of the regions, such as Amhara, Oromia, Benishangul, Southern Nation, Nationalities and People, and Tigray Regional States.

The Amhara national regional state has attempted to recognize different people residing in the region better than other regions. In its preamble and Articles 8, $45(2,3)$ and 70(1), the Amhara National Regional State Constitution attempts to recognize the existence of minority ethnic groups in the region and it recognizes that all residents of the region are equal. Moreover, Article 39 gives constitutional recognition to the region's Oromo and Agew people. For instance, Article 39(6) of the Amhara Regional State Constitution declares that "the national rights stipulated under sub-article 1-5 of this Article hereof shall apply with respect to the peoples of Himra, Awi, and Oromo as well." To this effect, the two nationalities (i.e., Agew and Oromo) have been set up to establish their own nationality administrative zones.

Amhara National Regional State Constitution thus upholds the right to self-government of some ethnic minorities in the region. Beken noted that the Amhara regional state constitution in addition to the Amhara, explicitly refers to the Agew Himra, Awi, and Oromo ethnic groups. ${ }^{90}$ Aside from the Agew and Oromo minority nationalities, the Amhara regional state has also passed legislation to establish Argoba Special Woreda in the region. In

${ }^{90}$ V. B. Christophe (2015), 'Federalism, Local Government and Minority Protection in Ethiopia: Opportunities and Challenges', Journal of African Law, 59, pp. 150-177. Doi: $10.1017 / \mathrm{S} 0021855314000205$ 
accordance with the law, the Argoba nationality Woreda was established for the Argoba minority in the Amhara region. ${ }^{91}$

However, apart from the above-mentioned minority nationalities, there are other ethnic minorities that have lived in the region for a long period of time. For example, the nationalities of Kemant, Gumuz, and Shinasha, among others, have lived in the region for many years. Nonetheless, the Amhara Regional State Constitution or other legislation does not recognize these ethnic minorities. It can also be stated that much effort was made in the region, for example, to replace the Kemant identity with Amhara. For instance, empirical information gathered by this author from some Kemant individuals indicates that the Kemant language is nearly extinct at the moment.

The total population of Kemant people was estimated to be 172,000 in the 1994 population and housing census. However the Kemant people were removed from the census document in the 2007 population and housing census. The Gumuz community also inhabits various Kebeles such as Afetete, Shunifa, Tummat, Metrhat, Seferdb, Banbo, Dibaba, Bermil, and Mehadid on the side of the west region up to Metemma Woreda in the North Gonder Zone, Quara Woreda. ${ }^{92}$ The regional state constitution, however, does not recognize the local Gumuz community. Furthermore, the Shinasha community is very prevalent in Gojjam areas, particularly in Shindi district or Woreda. The Shinasha, like the Kemant, have lost their identity, which has been replaced by the identities of the Amhara and Agew. Yet, there is a positive recent development towards the recognition of the Kemant people's right to self-government and identity.

In view of the foregoing, it can be concluded that there are gaps in the handling of the rights of ethnic minorities within the Amhara National Regional State. It is worth noting that this situation is having a negative impact on the federal system. The FDRE Constitution recognizes equality for all nationalities, and requires political representation for all nations, even at various political institutions. It requires the representation at different levels of government, but it can be stated that this constitutional provision is not adequately implemented in the Amhara region.

With regard to the Oromia Regional State Constitution, it does not hesitate to provide acknowledgment to ethnic minorities. However, the preamble, only makes reference to the Oromo people. For example, the

\footnotetext{
${ }^{91}$ Refer to Argoba Nationality Woreda Establishment Proc No 130/2006 of Amhara Regional State.

92 The author's field observation, 2019.
} 
preamble reads "we, the people of the Oromo nation." However, it is clear that there have been other minority ethnic groups living in the Oromia region for many years. For example, Amhara and Shinasha have settled in the region for many years. Moreover, here is no systematic arrangement for equitable representation and participation at different levels of government in the region. In fact, it is a prerequisite and mandatory to speak and write the Oromiffa language to participate in various government structures, exercise the right to vote, and be elected under the regional state constitution.

Although some scholars try to refer to this constitutional provision as an inclusive system in the region, it can be argued that this provision is not inclusive; rather, it is an exclusive constitutional provision towards minority ethnic groups. As language is an expression of identity, it can be said that the constitution excludes the existence and participation of minority ethnic groups in regional politics. It can also be said that, like the Amhara region and other regions, the region's nomenclature is exclusive, which is based on the Oromo people. In general, it can be said that the lack of fair treatment of ethnic minorities in the region has a negative impact on the federal system. This is because it is well known that the objective of the federal system of Ethiopia is to treat the nation, nationalities, and people properly. It can be argued that this constitutional provision is not being properly implemented in the Oromia region.

With regard to the Southern Nation, Nationalities and People's Regional State (SNNAPRS), it there are more than 55 regional owner nationalities in the region. The territorial ownership of the right to self-government within the region is limited to the owner nationalities of the region. It is known that the Amhara, Oromo, Tigray, Afar, Gambella, etc., have not been granted the right to self-government in the region. In fact, it is possible to mention that there are other minority ethnic groups other than the 55 owner nationalities residing in the SNNPRS, like the rest of other regions. For instance, hundreds of thousands of Amhara and Oromo live in the SNNPRS. However, it can be said that there is no system in place in the region for these other minority ethnic groups to govern themselves. Yet, Amharic is the region's working language in the SNNPRS. This has advantages for the region's minority ethnic groups. This is because minority ethnic groups are active in the region, making it easier for them to obtain government and other job opportunities.

Like other regional states, Tigray National Regional State is also a region where ethnic groups have been living for a long period of time. For example, in addition to the Tigray ethnic group, it is a region inhabited by the Kunama 
and Irob. It is worth noting that the Tigray Regional State Constitution recognizes minority ethnic groups. For example, the preamble and Articles 33, 39, and 45 of the Tigray National Regional State Constitution state that the rights of minorities within the region are respected and recognized. Moreover, the Kunama and Irob ethnic groups have been recognized at various levels of government structure to govern themselves.

With respect to the Benishangul Gumuz Regional State, the region is multi-ethnic. According to the Benishangul Gumuz Regional State Constitution, the Bertha, Gumuz, Shinasha, Mao, and Komo nationalities are owner nationalities of the region. In addition to the five owner-nationalities of the region, it is clear that other minority ethnic groups have lived in the region for years. For example, the Agew, Oromo and Amhara ethnic groups have lived in the region for a long period.

Ownership of the region is recognized in all regional states in Ethiopia. Other than its express articulation, Benishangul Gumuz Regional State is not thus unique to other regions in the country. According to empirical data gathered from various interviewees, the peaceful-coexistence of owner nationalities in BGRS and other minority ethnic groups has been harmed by this constitutional dichotomization. In contrast to this constitutional provision, it can be pointed out that the other minority ethnic groups at the Kebele and Woreda level have considerable political representation in different governmental bodies. ${ }^{93}$ This has positive effects. Because Amharic is the official language of the region it has its own positive implications for the protection of the rights of other minority ethnic group. As Amharic is also the official language of the federal government, this situation allows every citizen of the country to move to work in the region. However, at various levels of government, other nationalities have not been adequately represented, especially at the executive body of the regional state.

\section{Concluding Remarks}

The preceding sections have critically examined the pathologies and triumphs of federalism in Ethiopia. In a multi-national federation, the federal government is not the only level of government where group interests can be accommodated. Sub-national governments should thus manage existing diversity in accordance with their respective contexts. Ethnic conflict in contemporary Ethiopia also relates to the problems in the treatment of ethnic minorities that can be observed in all regional states.

${ }^{93}$ Muluneh K. (2021), supra note 56. 
This author argues that although ethnic federalism alone does not exacerbate ethnic conflicts in Ethiopia, ethnic-federalism, together with the existence of ethnic-based political parties and the hasty proliferation of narrow ethno-nationalist politics, has constituted a major impediment to peaceful coexistence among various ethnic groups in Ethiopia. In the context of ethnic federalism, organizing political parties primarily through the lens of ethnicity would gradually increase ethnic fundamentalism, chauvinism, and parochialism among politicians and individuals. It eventually allows politicians and individuals to engage in lopsided proxy ethnic political games within regional states, resulting in ethnic conflict. Hence, this type of political party establishment roadmap in the country has paved the way for a series of ethnic conflicts, resulting in major predicaments and conflicts among various ethnic groups in the country in general and in regional states in particular.

Therefore, I argue that the Ethiopian government should constitutionally ban the formation of ethnic based parties with a view to harnessing and controlling the destructive effects of the ethnification of politics in the country in general and the regional states, zones, woredas and local community units in particular. During the 1991-2018 TPLF-led EPRDF leadership, ethnic entrepreneurs have worked tirelessly to promote and entrench identity politics analogous to the transformation of water in a refrigerator into ice. As the logical anti-thesis to this approach of the TPLFled EPRDF regime, I argue that the current government at federal and regional state levels must work hard to ensure that identity-based politics should incrementally melt like salt in water. 
December 2021

\section{Cited References}

Aalen, L. (2002). Ethnic-federalism in a Dominant Party State: The Ethiopian Experience 1991-2000, Bergen: Chr. Michelsen Institute.

Abbink, J. (1997). 'Ethnicity and Constitutionalism in Contemporary Ethiopia', Journal of African Law,

Adeyemi in Ubani, C. (2014). 'Political Parties and National Integration: An Assessment of the Nigerian State since Independence', Covenant University Journal of Politics and International Affairs, Vol. 2

Alem Habtu (2010). Ethiopian Federalism: Principle, Process and Practice, ed. Prepared for the 5th International Conference on Federalism. Addis Ababa: Addis Ababa University Press.

Alene A. and Worku D. (2016). 'Does Ethnic-federalism Exacerbating or Reducing Conflicts? The Ethiopian Federal Experiences', International Journal of Emerging Trends in Science and Technology, 4838-4845.

Anderson, George (2008). Federalism: An Introduction, Oxford: University Press.

Anderson, Liam D. (2012). Federal Solutions to Ethnic Problems: Accommodating Diversity, Routledge

Apparodai, A. (1968). The Substance of Politics, OUP, London.

Asnake Kefale (2013). Federalism and Ethnic Conflict in Ethiopia: A Comparative Study of the Somali and Benishangul-Gumuz Regions, New York: Routledge.

Assefa Fiseha (2007). Federalism and the Accommodation of Diversity in Ethiopia: A Comparative Study, revised edition, Addis Ababa: Artistic Printing Enterprise.

Beken, C. V. (2012). Unity in Diversity-Federalism as a Mechanism to Accommodate Ethnic Diversity: the case of Ethiopia, Berlin: Deutsche Nationalbibiliothek.

Burgess, M. (2006). Comparative Federalism: Theory and Practice, Abingdon, Oxon: Routledge.

Christophe, V. B. (2015). 'Federalism, Local Government and Minority Protection in Ethiopia: Opportunities and Challenges', Journal of African Law, 59, pp. 150-177

Duchacek, Ivo D. (1970). Comparative Federalism: The Territorial Dimension of Politics, New York: Holt, Rinehart, \& Winston.

Ejobowah, J. (2001). Competing Claims to Recognition in the Nigerian Public Sphere: A Liberal Argument about Justice in Plural Societies, Lanham: Lexington Books.

Elazar, D. (1987). Exploring Federalism, Tuscaloosa, AL: University of Alabama Press.

Fathe Mahdi Wozir \& Muluneh Kassa Erreso (2021). 'Protection of indigenous minority voting rights in the Ethiopian electoral system: The case of Harari National Assembly', Journal of Social and Administrative Sciences, Vol. 8, pp. 91-110. doi: http://dx.doi.org/10.1453/jsas.v8i3.2236.

Filippov, M. (2005). 'Riker and Federalism', Constitutional Political Economy, vol. 16, pp. 93-111. Doi: 10.1007/s10602-005-2230-x.

Gutmann, A. (1994). Multiculturalism: Examining the Politics of Recognition. 41 William Street: Princeton University. 
Hale, H. (2004). 'Divided We Stand: Institutional Sources of Ethno federal State Survival and Collapse', World Politics, 56

Hrbek, Rudolf (ed.) 2004. Regional Parties and Party Systems in Federal States (Baden-Baden: Nomos Verlag)

Ishiyama, John (2009). 'Do Ethnic Parties Promote Minority Ethnic Conflict?, Nationalism and Ethnic Politics, 15:1, 56-83, DOI: 10.1080/13537110802672388.

John, M. (2011). Ethiopia: The Last Two Frontiers, Oxford, England: James Currey.

Keller, E. (1998). 'Regime change and ethno-regionalism in Ethiopia: The case of Oromo' in Asafa Jalata (ed.), Oromo nationalism and the Ethiopian discourse: The search for freedom and democracy, Lawrenceville New Jersey: The Red Sea Press,

Kymlicka in Turton, D. (ed.), 2006. Ethnic Federalism: The Ethiopian Experience in Comparative Perspective, James Currey Ltd. Oxford.

Majeed, A., Isawa, J. et al (2008). Building on and Accommodating Diversities, in Watts, R., Chattopadhyay, R. (eds.) Unity in Diversity Learning From Each Other (Volume 1) Building on and Accommodating Diversities, pp. 3-20, New Delhi: Forum of Federations.

Markakis, J. (2003). 'Conflict in pre federal Ethiopia', First national conference on federalism, conflict and peace building Addis Ababa: Ministry of Federal Affairs, pp. 11-24.

Mohammed Hassen (1999). 'Ethiopia: Missed opportunities for peaceful democratic process' in Kidane Mengisteab and Daddieh, Cyril (ed.), State building and democratisation in Africa. Westport: Praeger.

Moreno, L. and Colino, C. in Moreno, L. and Colino, C. eds., (2010). A global dialogue on federalism, diversity and unity in federal countries. Vol. 7, McGill -Queen's University.

Muluneh Kassa Eresso (2021). The Praxis of Unity in Diversity at Sub-National Governments in Ethiopia: An Empirical Analysis of Benishangul-Gumuz Regional State Practice, Dodo Books Indian Ocean Ltd.: Lap LAMBERT Academic Publishing.

Neumann in Horowitz, D. (1985). Ethnic Groups in Conflict, California: University of California Press.

O'Leary, Brendan (2004). 'Building Inclusive States,' Human Development Occasional Papers (1992-2007) HDOCPA-2004-09, Human Development Report Office (HDRO), United Nations Development Programme (UNDP).

Philip, S. (2000). Kant, Duty and Moral Worth, London, Routledge.

Richards, Peter Judson (2008). 'Hugo Grotius, Hosti Humani Generis, and the Natural Law in Time of War,' Liberty University Law Review, Vol. 2, pp. 881-908.

Riker in Volden, C. (2004). 'Origin, Operation, and Significance: The Federalism of William H. Riker', Publius: The Journal of Federalism, 34 4, pp. 89-108.

Riker, W. (1964). Federalism: Origin, Operation, and Significance. Boston; Toronto: Little Brown and Company.

Roeder, P. (2009). 'Ethno federalism and the Mismanagement of Conflicting Nationalisms', Regional and Federal Studies, 19(2). 
Sartori, Giovanni (1994). Comparative Constitutional Engineering: An Inquiry into Structures, Incentives and Outcomes, New York: New York University Press

Stein, Michael B. (1968). 'Federal Political Systems and Federal Societies', World Politics, 20

Stremlau, Nicole (2014). Media, Participation and Constitution-Making in Ethiopia. Journal of African Law, 58, pp .231-249. Doi: 10.1017/S0021855314000138

Tierney, S. (2004). Constitutional Law and National Pluralism, Oxford \& New York: Oxford University Press.

Watts, Ronald (2008). Comparing Federal Systems, $3^{\text {rd }}$ edition, Montreal; Kingston; London; Ithaca: McGill-Queen's University Press.

Wheare, K. (1963). Federal Government, $4^{\text {th }}$ edition, London: Oxford University Press.

Yonatan Tesfaye Fessha (2010). Ethnic Diversity and Federalism Constitution Making in South Africa and Ethiopia, England: Ashgate Publishing Company. 